\title{
An oral history try on the process of the foundation of Ankara University Faculty of Education
}

\author{
Mehmet SAĞLAM*
}

\begin{abstract}
With this study, the story of the establishment of the Ankara University Faculty of Educational Sciences is tried to be presented through making use of both the written documents and the narratives of three important people having an active role during the establishment of this process. Many of the developments, difficulties, and solution efforts taking place during the foundation period are tried to be introduced by the original narratives of Prof. Dr. Ihsan Doğramac1, Prof. Dr. Hamide Topçuoğlu and Prof. Dr. Yaşar Karayalçın. While the pre-faculty attempts to found educational faculties and their failures are seen in the written documents, the personal experiences and the lived things which cannot be seen in the written documents are hidden in the speeches of these people. Therefore, this study does not have a further state that aims to complete what is incomplete in the written documents.
\end{abstract}

Keywords: Faculty of Educational Sciences, Oral history, Ihsan Doğramacı, Hamide Topçuoğlu, Yaşar Karayalçın.

*Assist. Prof. Dr., Bozok University, Faculty of Education, Preschool Education Department, Yozgat, Turkey. E-mail: mehmet.saglam@bozok.edu.tr 


\section{SUMMARY}

The basic aim of this study is to reveal the narratives of those who played a significant role during the foundation of the Faculty of Education at Ankara University and the documents written about this foundation. While fulfilling this aim, certain written documents revealing vital information about the establishment process and the narratives of Prof. Dr. İhsan Doğramacı, Prof. Dr. Hamide Topçuoğlu and Prof. Dr. Yaşar Karayalçın are taken into consideration so as to display how difficult the foundation of Faculty of Education had been as there hadn't been any experience in this field before. In addition to this, we are able to see to what extent there appears any corelation between the written documents and narratives of these important figures. Moreover, it is clear to see that there are certain details reflected by these narratives are not able to be come across in the written documents. This helps us see how necessary oral history becomes to make historical studies more interesting. 


\title{
Ankara Üniversitesi Eğitim Fakültesi'nin Kuruluş Süreci Üzerine Bir Sözlü Tarih Denemesi
}

\author{
Mehmet SAĞLAM*
}

ÖZ. Bu çalışmayla, Ankara Üniversitesi Eğitim (Bilimleri) Fakültesi'nin kuruluş hikayesi, hem yazılı kaynaklardan hem de bu süreçte aktif görev alan ve katkıda bulunan önemli üç kişinin anlatılarına bağlı olarak sunulmaya çalışılmaktadır. Kuruluş döneminde yaşanan pek çok gelişme, güçlük ve çözüm çabaları Prof. Dr. İhsan Doğramac1, Prof. Dr Hamide Topçuoğlu ve Prof Dr. Yaşar Karayalçın'ın kendi orijinal anlatılarıyla ortaya konulmaya çalışılmaktadır. Fakültenin kurulmasından önce eğitim fakültelerinin kurulmasına yönelik yapılmış olan girişimler, bunların başarısızlıkla sonlanması daha çok yazılı kaynaklarda görülürken, yazılı kaynaklarda rastlamadığımız bireysel deneyim ve yaşanmışlıklar ise o süreci birebir yaşayan bu önemli üç kişinin anlatılarında gizlidir. $\mathrm{Bu}$ vesileyle bu çalışmanın anlatılarla, yazılı belgelerde eksik olanı tamamlama çabasından öteye bir iddiası bulunmamaktadır.

Anahtar Sözcükler: Eğitim Fakültesi, sözlü tarih, İhsan Doğramacı, Hamide Topçuoğlu, Yaşar Karayalçın.

*Yrd. Doç. Dr., Bozok Üniversitesi, Eğitim Fakültesi, Okul Öncesi Eğitimi ABD, Yozgat, Türkiye. E-posta: mehmet.saglam@bozok.edu.tr 


\section{GíRiş}

Bu çalışma, Ankara Üniversitesi Eğitim Fakültesi’nin kuruluş sürecini sözlü tarih yöntemiyle anlatmaya çalışmaktadır. Daha önce fakültenin kuruluşuna yönelik önemli çalışmalar yapılmıştır. Fakültenin kuruluşunda önemli katkıs1 bulunan Prof. Dr. Cemal Mihçıŏlu'nun "Eğitim (Bilimleri)Fakültesinin Kuruluşu Üzerine” adlı çalışmas1 fakültenin kuruluşuna özgü önemli ayrıntılar sunmaktadır (Mıhçığlu, 1989). Bunun yanı sıra Prof. Dr. Hamide Topçuoğlu'nun "Ankara Üniversitesi'nin Bir "Eğitim Fakültesi" Vardır!" adlı makalesi bize fakültenin kuruluş aşamasındaki güçlüklerini ilk ağızdan sunmaktadır (Topçuoğlu, 1971). Ayrıca Prof. Dr. Cavit Çavdar'ın “Ankara Üniversitesi Eğitim Fakültesi 1975-1976" adlı çalışması fakültenin ilk yıllarındaki sayısal verileri hakkında detaylı bilgiler vermektedir (Çavdar, 1976). Bu detaylı çalışmaların dışında fakültenin kuruluşunun 40. yıl dönümüne özgü hazırlanmış olan özel sayıdaki çalışmalar, fakültenin kuruluşuna yönelik detaylı bilgiler bulunmaktadır. Bu çalışmalar arasından Prof. Dr. İnayet Aydın ve Doç Dr. Yasemin K. Kepenekçi'nin “Ankara Üniversitesi Eğitim (Bilimleri) Fakültesi'nin Kurucularından Yaşar Karayalçın:Yaşam ve Eğitim (Bilimleri) Fakültesi Öyküsü ve Eğitim (Bilimleri) Fakültesi’nin Kurucu Dekanı: Prof. Dr. Hamide Topçuoğlu” adlı çalışmaları kısmi sözlü tarih yöntemiyle yapılmış olup hem iki önemli hocanın yaşamından kesitler sunmakta hem de fakültenin kuruluş sürecinin anlaşılmasında önemli katkı sağlamaktadır (Aydın ve Kepenekçi, 2008).

Tüm bu değerli çalışmalara katkı olması bakımından, sözlü tarih yöntemiyle yapılmış olan bu çalışma fakültenin kuruluş atmosferini birebir yaşayanların anlatılarıyla ortaya koymayı hedeflemektedir. Bu çalışmayla yazılı belgelerde karşılaşamadığımız önemli ayrıntıları görebilmekteyiz. Yazılı belgelerde fakültenin kuruluşu esnasında yapılanlar bulunurken, anlatılarda ise daha çok kuruluş sürecinde birebir yaşananlar, güçlükler, kuruluş ve devamında aktif görev alanların yaşadıkları bulunmaktadır.

\section{YÖNTEM}

$\mathrm{Bu}$ çalışmanın yöntemi sözlü tarih yöntemidir. Bu yöntemle, fakültenin kuruluşuna öncülük etmiş ve katkıda bulunmuş kişilerin yazılı kaynaklarda bulunamayacak deneyimleri açığa çıkarılmaya çalışılmaktır. Fakültenin kuruluşunda aktif rol almış bulunan dönemin Ankara Üniversitesi rektörü Prof. Dr. İhsan Doğramacıŏlu ile 24 Haziran 2005, fakültenin dekanı Prof. Dr. Hamide Topçuoğlu ile 20 Haziran 2005 ve öğretim üyesi Prof. Dr. Yaşar Karayalçın ile 6 Temmuz 2005 tarihlerinde araştırmacı tarafından görüşmeler yapılmıştır. Önceden izinleri alınmak koşuluyla yapılmış olan 
görüşmelerin ses kaydı alınmıştı ve daha sonra da bu görüşmeler yazılı metne dönüştürülmüştür. Kuruluş aşamasında bu kişiler arasında geçen diyaloglar bize birebir yaşanmış olanları yansıtmaktadır. Bu tür diyaloglara yazılı belgelerde pek rastlanmaz ayrıca bu anlatılar o dönemin yeniden kurgulanmasında bize yardımcı olur.

Sözlü tarihin klasik tarih yazımından en önemli farkı bireysel deneyimi ön plana çıkarmasıdır (Tan, 2000; Sağlam, 2010). Sözlü tarih geçmişte yaşanmış olayları yaşayanların belleğinden ve onların yaşam öyküleri çerçevesinde toplayarak kaydetmeye dayanmaktadır (Tan, 1996). Sözlü tarihin temel kaynağı insanların söyledikleri ve geçmişle ilgili belleklerinde yer edinilenlerdir (Tuncay, 1993). Bu yöntemle bireysel deneyimleri yakalayarak belgelerde yer almayan ya da çarpitılarak yansitılan konuları aydınlatma olanağı olmaktadır (Tan, 1996). Sözlü tarih araştırmacıya yazılı belgeler kadar kaynak sağlamanın yanı sıra ona aynı zamanda yöntemden öte yazılı belgelerde mevcut olamayan detayları da sağlamaktadır (Öztürkmen, 2001: 53). Ayn1 zamanda sözlü tarih ürünleri olan yaşamöyküleri, tarihçilerin tarih yazarken öteden beri kullandıkları kaynaklara da alternatif olmaktadırlar. Sözlü tarih yöntemiyle, mesele salt materyal toplamaktan çok geçmişe anlam verme sürecine katkıda bulunulmaktadır (Caunce, 1994: 3-7). Sözlü tarih yaşamöykülerini korumayı ve onlara ulaşmamızı sağlamaktadır, aksi halde önem arz eden o yaşamöyküleri yok olur ve yapılacak olan araştırmalar da eksik kalırdı (Starr, 1984: 40).

Her ne kadar çalışmanın yöntemi sözlü tarih yöntemi olsa da o dönemde yazılmış olan kaynaklar ile anlatılar arasındaki benzerlik ve ayrışmaları görebilmek için fakültenin kuruluşu ile ilgili dönemin yazılı kaynaklarına da vurgu yapma ihtiyacı doğmuştur. Bu vesileyle bazı yazılı kaynaklarla fakültenin kuruluş süreci ve sonraki seyrinin de bir panoramasını çıkarılmaya çalışılmıştır.

\section{BULGULAR}

$\mathrm{Bu}$ bölüm, fakültenin kuruluşuna özgü yazılı belgelerde yer edinen gelişmeleri, kuruluş sürecinde rol almış önemli kişilerin anlatıları ve fakültenin kuruluşundan sonraki kısa seyrini kapsamaktadır.

\section{a) Yazılı Belgelerde Eğitim Fakültesi'nin Kuruluş Girişimleri}

1965 tarihine kadar farklı zamanlarda eğitim fakültesi kurma girişimleri olmuş ancak bu girişimler cılız kalmıştır. Kısaca bu girişimlerden söz etmek faydalı olacaktır. İlk girişim 1950'li yılların ortalarına doğru Demokrat Parti 
yönetimi döneminde Tevfik İleri’nin Milli Eğitim Bakanlığı sırasında Gazi Eğitim Enstitüsü'nün bir fakülte işlevini yerine getirebilecek bir yapıya kavuşturulması düşünceleri ortaya atılmış ancak böyle bir kurumun dört yıllık bir lisans öğretimi sunması ve üniversite düzeyinde bulunması gerektiği ileri sürülerek gerçekleştirilememiştir (Mihçıŏlu, 1989: 347). Diğer bir girişim Orta Doğu Teknik Üniversitesi tarafindan yapılmıştır. 1958 y1lında bu üniversitede bir eğitim fakültesi kurulmuş ancak daha sonra fen edebiyat fakültesinin öğretmen yetiştiren bölümüne dönüştürülmüştür (Mıhçıŏlu, 1989: 347-348). Bu iki girişim de başarısızlıkla sonuçlanmıştır.

Ayrıca VII. Milli Eğitim Şurası'nda da Yüksek Öğretmen Okullarının üniversiteye bağlı veya bir Eğitim Fakültesi haline getirilmesi gerektiği teklif edilmiştir. Buna ilave olarak, Eğitim Fakültelerinin aynı zamanda "Eğitim Araştırmaları Merkezleri” olarak organize edilmeleri ve eğitim alanında uzman, idareci, test ve araştırmacı gibi personeli yetiştirmek görevlerini üzerlerine almaları da teklif edilmiştir. "Eğitim Bilimleri Yüksek Enstitüsü" veya "Eğitim Bilimleri Akademisi" adıyla bir müessesenin kurulması da uygun görülmüştür. $\mathrm{Bu}$ kurumun önce özel bir kanunla Milli Eğitim Bakanlığı'na bağlı olarak kurulması, dört, beş yıl içinde de kuruluşu tamamlandıktan sonra üniversiteye bir fakülte olarak katılmasının doğru olacağı ileri sürülmüştür. (VII. Milli Eğitim Şuras1, 1962: 219). Bunun yanı sıra Merkezi Hükümet Teşkilatı Araştırma Projesi'ne (MEHTAP) göre Milli Eğitim Bakanlığı'ndaki idareci ihtiyacının karşılanabilmesi için üniversitelerin bünyesinde eğitim fakültelerinin kurulması gerektiği vurgulanmıştır (Merkezi Hükümet Teşkilatı Araştırma Projesi, 1966: 342-3).

Diğer bir girişim ise 1964 yılında Milli Eğitim Bakanlığ 1 müsteşarı Nuri Kodamanoğlu'nun hazırladığı "Üniversitelerimize Bağlı Eğitim Fakülteleri Kurulması Hakkında Rapor" başlığını taşıyan rapordur. Bu rapor 5 Mart 1964'te Milli Eğitim Bakanı İbrahim Öktem'in başkalığında toplanan Üniversiteleraras1 Kurul önünde okunarak üniversitelerin temsilcilerine sunulmuştur (Kodamanoğlu, 1964; Mihçığlu, 1989: 348). Bu rapor daha sonra Ankara Üniversitesi'ne bağlı olarak kurulacak olan Eğitim Fakültesi'nin zeminini hazırlamıştır.

Eğitim Fakültesinin kuruluşu ile ilgili hazırlanan raporda öğretmen okulları ile ilgili şu gerekçeler ileri sürülmüştür:

- Öğretmen okulları ilk kurulduğu yıllarda mezunlarına, bu mesleğin gerektirdiği meslek bilgisi ve mahareti kazandıramamıştır.

- Öğretmen okulları, kalite ve nicelik yönünden, ihtiyaca göre planlanmamıştır.

- Öğretmen yetiştiren kurumlarda eğitim bilimleri ikinci derecede kalmıştır. 
- Eğitim biliminin eksikliğinin giderilmesi için Gazi Orta Muallim Mektebi bünyesinde açılmış olan Pedagoji Şubesi ihtiyaca cevap verecek yeterlilikte değildir. Yüksek Öğretmen Okullarında ise asıl konu ilim dallarında yetişmek olduğu için, eğitim bilimi gelişme imkanı bulamamıştır (Kodamanoğlu, 1964).

Kurulması düşünülen Eğitim Fakültelerine yönelik yapılan toplantılarda Ankara Üniversitesi, İstanbul Üniversitesi ve Ege Üniversitesi'nin temsilcileri bulunmuştur; çünkü bu üniversitelerin bulunduğu üç büyük kentte birer eğitim fakültesi kurulması öngörülmekteydi. Toplantılarda daha çok Profesör Lauwerys'in görüşleri ağırlık taşımış ve onun görüşleri karara bağlanmıştır. Yeni kurulacak olan fakültenin, üniversitenin daha önce kurulmuş bulunan fakültelerine eğitim yöntemleri, özellikle de ölçmedeğerlendirme alanında yardım sağlaması düşünülmekteydi. Bunun nedeni ise şuydu: Türkiye'de bütün öğretmenler, ilköğretim öğretmenleri dahil öğrenimleri sırasında eğitim yöntemleri konusunda aydınlatılır, kendilerine bu alanda bilgi ve beceriler kazandırılır. Bunun aksine üniversite öğretim üyeleri, kendi uzmanlık alanlarında geçirecekleri bir sınavla asistan olarak göreve başlarlar. Ölçme-değerlendirme konusunda herhangi bir eğitim görmeden, sadece kendi uzmanlık alanlarındaki bilgilerini geliştirerek yükselirler (Mihçıŏglu, 1989: 351-352).

Kurulacak eğitim fakültelerinin başlıca çalışma alanları olarak şunlar düşünülmüştü (Mıhçığlu, 1989: 353-355);

- Öğretmenler için hizmet içi eğitim

- Araştırma projeleri

- Öğretim-araştırma

Öğretim-araştırma çalışmaları bölümler çerçevesinde düzenlenmeliydi. Her bölümün başında bir profesör bulunmalı ve kürsüler ilgili bölümler içinde yer almalıydı. Bu bölümlerin şunlar olması düşünülüyordu:

- Eğitim Felsefesi-Tarihi Temelleri

- Eğitimin Toplumsal Temelleri

- Eğitimin Psikolojik Temelleri

- Örgüt-Yönetim

- Eğitim Kurumu ile Uygulamas1

Eğitim fakültelerinde yetiştirilecek görevli türleri üç grupta toplanacaktı. Bunlar, lise öğretmenleri, eğitim uzmanları ve özel eğitim öğretmenlerinden oluşmaktaydı.

$\mathrm{Bu}$ toplantılardan sonra ortaya çıkan görüşler, karşılaşılabilecek sorunları da kapsamaktaydı. Bu meselelere yönelik kararlar belirlendi. Örneğin, yurt dışından getirilecek uzmanlar ile ilgili mesele önemliydi. Profesör Lauwerys en az altı uzmanın getirilmesi gerektiği düşüncesini ileri 
sürmekteydi. Bu sayıda uzmanı tek ülkede sağlamanın güç olacağını ve bu yüzden ikisi İngiltere'den, ikisi Birleşik Amerika'dan, ikisi Belçika, İsviçre ve Almanya'dan olmak üzere altı bilim adamının getirilmesini önermekteydi (Mihçıŏlu, 1989: 353-355).

J. A. Lauwerys'ın Milli Eğitim Bakanına “Ankara Üniversitesi Eğitim Fakültesi kurulması hakkında hazırlamış olduğu raporda" bir Eğitim Fakültesi tarafindan izlenecek amaçlar şu şekilde belirlenmişti (Çavdar, 1976: 125):

a) Liseler ve öğretmen okulları için gittikçe artan sayıda kalifiye öğretmene ihtiyaç duyulmaktadır. Bu, orta öğrenim ikinci devresi ile ilgilidir. Türk lisesinin durumu trajiktir; daha önce var olan yüksek standartlar ve bu kurumların gelenekleri, öğretmen yetersizliği yüzünden gittikçe bozulmaktadır. b) Eğitim ve Öğretmenlik Formasyonunu Gazi ya da Eğitim Enstitüleri (v.b.) kurumlarda alanlar için, üniversite derecesi dahi, yüksek akademik liyakat yollarını açmak büyük bir önem taşımaktadır. c) Türk Milli Eğitim sisteminin gelişmesi ve bu sanayileşmenin doğuracağı taleplere hızlı adapte olması için geniş ve kapsayıcı araştırma gerekmektedir. d) Yukarıda sıralanmış olan amaç ve erekler, öncelikle Ankara'dan sonra İstanbul ve İzmir gibi üniversite merkezlerinde, kısmen otonom kurumlardan meydana gelen bir federasyon halinde Eğitim Fakültesi açarak gerçekleştirilebilir (Çavdar, 1976: 125-126).

Başlangıçta üç büyük kentte aynı anda üç eğitim fakültesinin kurulması düşünülmüştür. Ancak daha sonra gerek iç olanakların kısıtlı oluşu, gerekse dışarıdan çok sayıda nitelikli uzman getirilmesi gerektiği ve bunun güçlüğü bunu engellemiştir. Bu yüzden önce Ankara'da, iki yıl sonra İstanbul ve dört yıl sonra da İzmir'de birer eğitim fakültesinin kurulmas1 kararlaştırılmıştır. Bu plana rağmen, öngörülen sürelerde İstanbul ve İzmir'de kurulması düşünülen fakülteler de kurulamamıştır.

Diğer bir konu da kurulacak eğitim fakültesinde ele alınması geren araştırma konuları ile ilgiliydi. Bu konular toplumun kalkınması, kentlere göç eden köylülerin uyumuyla ilgili sorunlar ve eğitimin ekonomisi ve finansmanı ile ilgiliydi. Ayrıca kendileriyle kolaylıkla ilişki kurulabilecek yakınlıktaki eğitim enstitülerinin de kurulacak eğitim fakültelerine bağlanmaları öngörülmüştü. Şimdilik ilk öğretmen okulları eğitim fakülteleri düzeninin dışında tutulmalıydı. Kurulacak eğitim fakülteleri başlangıç itibariyle sadece orta öğretime öğretmen yetiştiren kurumlarla ilgilenmeli ve bu kurumlarla aralarında eşgüdüm bağı kurulmalıydı (Mıhçığlu, 1989: 355356).

Dönemin rektörü İhsan Doğramacı'nın isteği üzerine 15 Temmuz 1964 Perşembe günü Ankara Üniversitesi Rektörlüğü'nde, kurulması tasarlanan Eğitim Fakültesi konusunda ilk toplantı yapıldı. Toplantı sonucuna göre 
Cemal Mıhçıoğlu'nun başkanlığında, Aydın Sayılı ile Hıfzırrahman Raşit Öymen'den kurulu üç kişilik bir icra komitesi oluşturuldu. Daha sonra 27-28 Temmuz 1964 günlerinde fakültenin kuruluşu ile ilgili olarak Ankara'ya gelmiş olan İngiliz Profesör Joseph Lauwerys ve Milli Eğitim Bakanlığı müsteşarı Kodamanoğlu'nun katıldığı bir toplantı yapıldı ve eğitim fakültelerinin kurulmasıyla ile ilgili sorunlar tartışıldı (Mıhçıoğlu, 1989: 350-351).

Tüm bu tartışmaların ardından Eğitim (Bilimleri) Fakültesi, Ankara Üniversitesi Senatosu'nun 31. 03. 1964 tarih 463/2718 say1l karar1 ile kuruldu ve 1965-1966 öğretim yılında da öğretime başladı. Fakültenin kuruluş amaçları; a) ülkemizde eğitimle ilgili çeşitli sorunların bilimsel yöntemlerle akademik düzeyde araştırılmasını ve toplumumuz için en uygun çözümlerin bulunmasını sağlayacak bilim adamları yetiştirmek, b) öğretmen yetiştiren okullara öğretmen yetiştirmek, c) eğitim bilimlerindeki çağdaş gelişmelerin ortaya çıkardığı uzmanlık alanlarına eleman yetiştirmek, d) üniversite öğrencilerinden ileride öğretmen olmak isteyenlere öğretmenlik formasyonu vermek, e) mezuniyet sonrası eğitimin ülkemizde sağlanmasına çalışlarak eğitimde doktora derecesini vermeye yönelik ihtisas eğitiminde bulunmak şeklindedir (Koç, 2008: 24).

"Eğitim Fakülteleri Kuruluş ve Kadro Kanunu Tasarısı" üniversitelerin görüşlerini bildirmeleri için üniversitelere gönderilmişti. Özellikle İstanbul Üniversitesi'nde üç profesörün hazırladıkları 30 Nisan 1965 günlü görüş bildirme yazısı bu tasarının oluşmasında etkili oldu. $\mathrm{Bu}$ arada eğitim fakültesinin kurulma çalışmalarına bir yüksek öğretmen okulu-eğitim enstitüsü çekişmesinden kaynaklanan ve özellikle de Gazi Eğitim Enstitüsü’nün öncülüğünü yaptığı bir kesimden ciddi bir tepki geldi. 10 Ekim 1965 milletvekili seçimleri ve sözünü ettiğimiz bazı kısır çekişme ve tartışmalardan dolayı bu tasarı yasallaşamadı. Bunun üzerine Ankara Üniversitesi fakülteye kendi kadro olanaklarıyla işlerlik kazandırmaya çalıştı (Mıhçığlu, 1989: 357-358) ve üniversitenin rektörü Prof. Dr. İhsan Doğramacı fakültelerinin profesör kurullarının kararları ile Üniversite Kanunun 62. maddesine dayanarak, iki yıl süre ile, Eğitim Fakültesi'ni faaliyete geçirmek için üç ayrı fakülteye ait altı öğretim üyesinden bir kurucu heyet görevlendirdi (Topçuoğlu, 1969: XIV ).

$\mathrm{Bu}$ heyet, 8 Temmuz 1965 günü Prof. Dr. Hamide Topçuoğlu'yu dekanlığa seçerek kuruluş çalışmalarını başlattı. Bu çalışmaların sonunda Temmuz 1965 tarihinde fakülte, Hukuk Fakültesi'nin arkasındaki, bir zamanlar İlahiyat Fakültesi'nin eğitim ve öğretimini sürdürdüğü ve daha sonra Adalet Yüksek Okulu'nun bulunduğu blokun bir bölümünde çalışmaya başladı (Mıhçığlu, 1989: 358). 1966-7 yılında fakültenin öğrenci sayısı iki yüze ulaşınca bir süre Hukuk Fakültesinin yardımlarından faydalanılmış 
olundu ancak İlahiyat Fakültesinin kendi binasına taşınmasıyla Eğitim Fakültesi dar da olsa müstakil bir binaya kavuşmuş oldu (Topçuoğlu, 1969: XXV).

Ancak fakültenin gerekli bütçeyle kadro sağlanamaması durumunda çalışmalarını sürdürmesi olanaksızdı. Bundan dolayı "Ankara Üniversitesi Kuruluş Kadroları hakkındaki 5239 sayılı Kanuna Ek Kanun" taslağı 2 Ağustos 1966 günü TBMM tarafindan kabul edilip yasallaştı ve Eğitim Fakültesi'nin amaçları şu şekilde belirlendi: a) Memleketimizde eğitim ile ilgili çeşitli problemlerin bilimsel metotlarla akademik seviyede araştırılmasını ve toplumumuz için en isabetli hal suretlerinin bulunmasını sağlayacak bilim adamları yetiştirmek. b) Orta dereceli öğretmen yetiştiren kurumlara meslek dersleri öğretiminde bulunacak öğretim üyesi ve ögretmen yetiştirmek. c) Orta dereceli okullara rehberlik, okul psikologluğu, idarecilik alanında eleman hazırlamak. d) Üniversite öğrencilerinden, ilerde öğretmen olmak isteyenlere öğretmenlik formasyonu vermek. e) Mezuniyet sonras1 eğitiminin memleketimizde sağlanmasına çalışarak eğitimde doktora payesini bahşedecek ihtisas öğretiminde bulunmak (Mıhçığlu, 1989: 358359; Topçuoğlu, 1969: XXI-XXII; Koç, 1999: 19; Ataman, Dirik ve Koç, 1976: 3).

$\mathrm{Bu}$ ifadeler Türkiye'de kurumların kuruluşuyla ilgi bir noktaya dikkatimizi çekmektedir. Özellikle "babasız çocuk gibi" ifadesi kurumların ihtiyaca göre önceden planlı ve programlı bir şekilde kurulmadığını daha çok kurulsun o kendisi halleder ve zamanla işlevini yerine getirir anlayışını göstermektedir. Fakültenin bütçe kanunun zamanında çıkmamış olması, "Eğitim Fakülteleri Kuruluş ve Kadro Kanunu Tasarısı"nda ki aksaklıklar bu görüşü desteklemektedir. Üniversite kendi imkânlarını kullanarak fakültenin işlevini yerine getirmesini olanaklı kılmıştır.

\section{b) Anlatılarda Eğitim Fakültesi’nin Kuruluşu}

Ankara Üniversitesi Eğitim Fakültesi’nin kurulma sürecini dönemin rektörü Profesör İhsan Doğramacı şöyle anlatmaktadır:

Ben 63 yılında Ankara Üniversitesi Rektörlüğ̈̈ne seçildim. $O$ dönemde rektörlük iki sene içindi ve rektörlük sürecinde üniversiteden eksikler nelerdir bunu incelerken eğitimle ilgili bir fakültenin bulunmaması dikkatimi çekti. $O$ dönemde bir fakültenin kurulması senato kararı ve Milli Eğitim Bakanı'nın onaylyla gerçekleşiyordu. Bir Eğitim Fakültesinin çalışmalarına başladık. Bu iki etaptaydl. Biri senatodan karar çıkarmaktı. O bizim görevimizdi, onu yaptı. Ondan sonra da Milli Eğitim Bakanı'nın onayı, onu zaten daha önceden anlaşarak karara 
bağlamıştık. $O$ da derhal onayladı. Bu arada ne gibi program uygulanırdı. Çeşitli ülkelerden örnekler önümüzdeydi. İngiltere örneği uygun görüldü. Ve oradan tanınmış uzmanlardan birinin davet edilmesi karara bağlandl. Bu gerçekleşti. Onlar, gelenler bilhassa Ingiltere'den gelen uzman çok yararlı oldu.

Hamide Toçuoğlu, İhsan Doğramacı'nın Fakültenin kurulmasında ciddi bir gayret sarf ettiğini şu sözlerle ifade etmektedir:

Olayı sahiplenen İhsan Bey'dir, İhsan Doğramacıdır. 1966 sensi midir? Seneyi hatırlamaya çalışıyorum. 1966 senesiydi zannediyorum. Eğitim Fakültesi'nin çıkmasını mümkün kılan bütçe kanunu düşer. İs tamamen muallakta kalır ve onun üzerine Ihsan Doğramacı mevzuu canlı tutmak ister.

Yine kuruluş aşamasında Yaşar Karayalçın İhsan Doğramacı'nın kendisini telefonla arayışını ve kendisine teklif edilen görevi kabul edişini şu şekilde nakletmektedir:

Ben Hukuk Fakültesi'nde Ticaret Hukuku hocastydim. Fakat eğitim konularıyla da yakından ilgilendiğim için bir gün bu tarihte üniversitenin de rektörü olan Sayın Doğramaci'dan bir telefon aldım. Sayın Doğramacı diyor ki biz bir Eğitim Fakültesi'ni kurmayı istiyoruz, düşünüyoruz. Bu Eğitim Fakültesi'nde sizin de kurucu ögretim üyesi olarak faydalı olacağınızı düşünüyorum. Bu önerimi kabul eder misiniz? Ben de kendisine teşekkür ettim ve benim için bunun ulvi bir hizmet olacağını belirttim. Bu sorumluluğu da kabul etmeye hazır olduğumu ilave ettim.

Yaşar Karayalçın fakültenin kuruluş amacını ve bu konudaki tartışmaları da şöyle ifade etmektedir:

Şimdi bana Sayın Doğramacı böyle bir öneride bulunduğu vakit, ben şunu düşündüm ve onun için bu hizmeti kabul ettim. Türkiye'de eğitim alanında iyi yetişmiş yöneticilere ihtiyaç vardır, araştırmalara ihtiyaç vardır. Avrupa'da eğitimin sosyal ve özellikle ekonomik yönleri tartışılmaktadır. Planlama konusu, eğitim alanında ön plana çıkmıştır. Bu itibarla ben şahsen şunu düşünüyorum. Bu amaçla kurulacak bir Eğitim Fakültesi'nde seve seve hizmet etmeye hazırım. Yalnız bu Eğitim Fakültesi eğer şeye, ögretmen yetiştiren bir fakülte olacak, olmak amaciyla kuruluyorsa bunun bir ikinci mükerrer bir çalışma olacağ kanaatindeyim. O tarihte liselere, ortaokullara, ilkokullara, 
öğretmen yetiştirmek amacıyla kurulmuş müesseseler vardl. Bu itibarla hizmet alanında böyle bir ayırma yapılmayacak olursa aynı işlevi yerine getirecek bir ek müessese kurulmuş olur ki bence de buna lüzum yoktur. Büyük Millet Meclisi 779 sayll yasa ile ilgili bir karar veriyor. Diyor ki bakınız rahmetli Mıhçıŏlu'nun çalışmasında belirtiliyor. Bir, memleketimizde eğitimle ilgili çeşitli problemleri bilimsel metotlarla akademik seviyede araştırllması ve toplumumuz için en isabetli hal suretlerinin bulunmasını sağlayacak bilim adamları yetiştirmek. Buna katıllyorum hiç şüphe yok. Zaten eğitimin amacı yani Eğitim Fakültesi kurulurken bu amaç ön plandaydı hiç şüphe yok. Ama arkasında yani yöneticileri yetiştirmek vesaire filan da benim kanaatime göre planlama konularının, eğitim ve planlama konularının araştırmak, onu yapacak kişiler yetiştirmek bu yeni fakültenin amacı olması gerektiği görüşündeydim.

Benim idealim bu Eğitim Fakültesi içinde yönetici kadro olarak, planlayıcı kadro olarak eğitimin mali yönleri, hukuki yönleriyle ilgili konuları araştırıp rehberlik yapacak, yön verecek seviyede kişiler yetişstirmek. Benim anladığım hizmet alanı buydu. Ve kürsülerin hazırlanması, tespit edilmesi safhasında tartışmalara stra geldiği vakit, eğitim ekonomisi ve planlanması konusunda bir kürsü ihdas edilmesini önerdim ve bu öneri başlangıçta kabul gördü. Bunun üzerine ben de, kendim hukukçuyum, eğitim konulartyla ilgileniyorum ama ben yani profesyonel yapıyorum, bir ögretim üyesiyim ama eğitim bu yönlerinde, bu konularında araştırma yapacak, ders verecek bir durumda değildim. Amacım o zaman bu kürsüyü kurmak ve özellikle ekonomi alaninda, bu alana bu yöne yönelmiş olan meslektaşların arasında bir kadro oluşturup derse başlamak idi. Fakat Siyasal Bilgiler'deki arkadaşlarla temas ettim, onlar ilgilenmediler.

Eğitim Fakültesinin kurulması gerektiği yönündeki resmi görüşmelerin dışında genel anlamda kamuoyu ve eğitim çevrelerinde fakültenin kuruluşuna yönelik birtakım olumsuz ve engel teşkil edecek düşünceler de vardı. Hamide Topçuoğlu ve Yaşar Karayalçın Fakültenin kuruluşuyla ilgili farklı yaklaşımları şu şekilde ifade etmektedir:

Bir görüse göre her profesör eğitimcidir, onlara ayrica bir eğitimden bahis etmek gereksizdir. Ĕgitimin diğer bilgi dallarından ayrı bağımsız karakteri ya da her branşa göre, yahut her ilim dalına göre diyelim isterseniz değişecek bir görünümü 
anlamsızdır. Memleketimizde biz hepimiz eğitimciyiz. Bunun ayrıca kendi başına bir bilim dalı olduğu iddiası mesnetsizdir tezini sık sık işitiriz. Dolayısıyla bă̆ımsız bir Eğitim Fakültesi her zaman tartışma konusu olmuştur. Bundan başka memleketimizde daha önceki yıllarda kurulmuş ve müesseseleşmiş Eğitim Enstitüleri vardır. Dolayısıyla bunların dışında yeni bir üniversite şubesi, fakültesi açmak gereksizdir tezini de savunanlar olmuştur. Şimdi bunun aslı şu kendilerine daha evvelden alıştı̆̆ımı Ĕ̈itim Enstitüleri vardır. Onlardan ayrı olarak ve üniversite camiası içinde müstakil bir fakülte kurmak gereksizdir tezini de savunanlar olmuştur. (Hamide Topçuoğlu)

Bu ilk toplantryla ilgili olarak pek çok şeyi hatırlyyorum çünkü benim için çok önemli bir toplantı oldu. Şimdi bu toplantıda rahmetli Mihri Mimioğlu zannediyorum Ziraat ve Veterinerlik Fakültesi'nden gelen bir hocaydl. Toplantıda söz ald ve şunu sordu: ben eğitimci değilim, yeni bir fakülte kurulurken bu konuda Avrupa'daki durumun ne olduğunu öğrenmek istiyorum. Bana Avrupa'daki Eğitim Fakülteleri'nin fonksiyonunu, sorumluluğunu anlatabilir misiniz? Dedi. Şimdi bunun üzerine aramızda eğitimle ilgili yani ĕgitimle ilgili sorumluluk taşıyan ögretim üyesi olarak sadece Bedi Ziya Egemen Bey vardl. Bedi Ziya Egemen Bey bu konuda söz ald ve uzun uzun Avrupa'da Ĕ̈itim Fakülteleri'nde yapılan eğitim hizmetlerini anlattı. Ben de bu konuşmayı biraz hayretler içinde dinledim. Konuşma oldukça uzun sürdü. Fakat sonradan Bedi Ziya Bey'den sonra söz aldım. Dedim ki, benim bildiğime göre Avrupa'da Eğitim Fakülteleri diye Edebiyat Fakülteleri'nin dişında bir organizasyon yoktur. Sayın Egemen'in anlattı̆̆ çalışmalar Edebiyat Fakülteleri'nin içinde bir enstitü çallşmaları olan, daha az seviyede hizmetlerdir. Tabi bu biraz soğuk duş tesiri yaptı. Bedi Ziya Bey, diğerleri hepimiz şey olarak yani profesyonel olarak eğitimci, yani hocaydık ama eğitim alanında özel olarak yetişmiş kişiler değildik. Kendi aramızda dahi bu tür problem, görüş farkları vardl. (Yaşar Karayalçın)

İhsan Doğramacı'nın anlattıklarına göre Fakültenin kurulmasına karşı ciddi bir tepki oluşmadi.

Genellikle iyi karşılandı diyebilirim. Ve her yeniliğe karşı bazen tepkiler olur. Bunun lüzumu var mı, ihtiyaç var mı? Filan 
gibilerinden, fakat büyük ölçüde olmadl. Genellikle olumsuz bir tepkiye rastlamadik.

Yaşar Karayalçın Fakültenin ilk yıllarına özgü yaşanmış olan bazı sorunları şöyle anılaştırmaktadır.

Yeni kurulmuş bir fakülte, şimdi şunu söyleyeyim. Yani ben hizmet döneminde Eğitim Fakültesi'ni, yani rektör Doğramacl destekliyor. Tabi kurduğu müessesenin elbette başarllı olmasını istiyor. O bakımda bizim rektörlükle bir problemimiz olmadl. Problemler öğrencilerimizdi. O hava içinde Fakülte bir nişan havası içinde, herkes aklına gelen veya gelmeyen, anladığ veya anlamadiğl her şeyi söyleyebiliyor. Bu hava içinde tabi üniversite, Eğitim Fakültesi tabi biraz sarsıldı. Ama dışarıdan böyle bir problem olduğunu zannetmiyorum.

Eğitim Fakültesi'nin kuruluş sürecinde daha önce kurulmuş olan eğitim kurumları, yeni kuruluyor olan ve eğitim ile ilgili tek fakülte olan Eğitim Fakültesi'nin kurulmasına sıcak bakmamışlardır. Bu durumu Hamide Topçuoğlu'nun anlatısında rastlamaktayız.

Akademik çevre dediğiniz mahalline masruf değil. Meslek mensupları arasında anlaşma uzlaşma değil rekabet ve husumet var.

Ayrıca Hamide Topçuoğlu fakülteyi yabancılar -Amerikalılar- kuruyor diye ciddi bir anti-amerikanizm tepkisinin oluşmuş olduğunu belirtmekte ve İsmet Paşa'nın Hukuk Fakültesi'nde yaptığı konuşmaya vurgu yapmaktadır.

Amerikalılar bunu kuracak dediler. Sonra anti-amerikanizm başladl. İsmet Paşa geldi, Hukuk Fakültesi'nde konuşma yaptı. 'Ben meclise hakim olayım sokağa da olurum'.

Fakültenin kuruluş ve oluşum sürecinde Yaşar Karayalçın bir toplantıda, ögrencilerle kendi arasında geçen olumsuz bir olayı şu şekilde anılaştırmaktadır:

Ben arkadaşlar, Hamide Hanım ayrıldıktan sonra dekan olarak seçtiler. Zannediyorum Hamide Hanım'dan sonra ben seçildim. Fakat o sıralarda öğrenci olayları çok tartışmalı geçiyor, anlamsız tenkitler yapılıyordu. Öğrencilerim geldi dedi ki: Efendim biz bir forum yapmak istiyoruz. Bize bir yer tahsis, salon tahsis eder misiniz? Dedim efendim, yalniz bu toplantiya ben arkadaşlarıma haber vereceğim, biz de katılmak isteriz. Toplantı yapıldı. $O$ zamanlar öğrenciler çok nişangahsı atışlarda bulunuyorlardl. Akll almaz şeylerden bahsediyorlardı ve biz ön 
sirada oturuyorduk. Büyük bir salondu ön sirada oturuyor, arkadan bizim öğrencilerin, benim ders verdiğim ögrencilerim oturuyorlardl. Öyle konuşmalar oldu ki "efendim bize gelen hocalar, Hukuk Fakültesi'nden gelen hocalar burada para kazanmak için geliyorlar." İ̧ste şunu yapıyorlar filan.

Bu seviyesiz konuşmalar epey sürdü. Onun üzerine söz aldım. Kalktım, çıktım kürsüye. Dedim ki: Arkadaşlarımızın söylediklerini iyi değerlendirdik, değerlendirdim. Yalnız size şunu söyleyeyim ki; Ankara Hukuk Fakültesi'nde gelen benim değerli meslektaşlarım buraya üç beş kuruş kazanmak için değil, bu Ĕgitim Fakültesi'ne, oluşmalarına hizmet etmek için geliyorlar. Katiyen bu görüşlere katılmak mümkün değildir, doğru değildir. Arkadaşlarımı böyle bir ithamda tenzih ederim. Ondan sonra şunu ilave etti: ben de dedim, diğer arkadaşlarım gibi buraya hizmet için geliyorum ve dekan olarak ta hizmet edebileceğim kanaatiyle bu görevi kabul etmiş bulunuyorum. Fakat dedim unutmayın dedim, siz hocalarınızın kıymetini biliniz, bilmeniz lazımdır. Bilmezseniz o zaman meşhur bir söz vardır ve şunu söyledim aynen. Bak utaniyorum bundan, bak kırk sene geçti. Bugünkü gibi hatırlyyorum. "Bir yerdeki sayini takdir edecek guğuş yok, taziyi nefes eyleme tebdili mekamet." Şair böyle diyor dedim. Bunun üzerine bir ses geldi. Efendim, ne demek bu? Bu şu demek: Bir yerde sizin emeğinizi takdir edecek kulak yok, insanlar yok ne uğraşıyorsunuz, yerinizi terk edin. Netice itibariyle tabi ben bu konuşan ögrencilerin sözlerine değil, daha ziyade o sözleri duyan kendi ögrencilerimin sessizliğine üzüldüm. Ne emeklerle hizmet ettiğimizi biliyorum ve bu kadar haksızlık olmaz dedim. Kendi kararımı verdim. Ben zaten ondan sonra bu konuşmaları yaptım. Toplantı bitti. Tüm arkadaşlar, yönetim komisyonu orda, yukarlya davet ettim dekanllk odasina. Dedim ki: Ben yarın İsviçre hukukçular, tüm hukukçuların toplantısı var, Isviçre'ye gidiyorum fakat size şimdi kararımı bildiriyorum. Ben artık bu kafadaki ögrencilere, kişilere hizmet vermem, arkadaşlarım ne düşünüyorlar bilmem. Ben dekanlıktan da burada ki ögretim üyeliğinden istifa ediyorum. Dekan olarak yarın için yurt dişına gideceğim için benim yerime filanca dekanlığl vekâleten yürütecektir. Hemen daktiloda yazdırdım bir tanesini rektörlüğe bir tanesini de Anadolu Ajansina gönderilmek üzere imzaladım ve ertesi gün sabahleyin erkenden biz uçağa bindik, Ísviçre'ye gittik. Bu itibarla bu tarihte benim Ĕ̈itim Fakültesi’yle ilişkim kesildi. 
Fakültenin kurulmasına karşı tavır alan çevrelerin bir kısmında insanların doğuştan idareci, yaratılış itibariyle eğitimci olabileceklerine ilişkin önyargılar vardı. Bunun dışında kader saikiyle öğretmenliğe başlamış kişilerin, düzenli eğitim formasyonu görenden daha başarılı olabilecekleri gibi iddialar savunulmaktaydı. Bu tür önyargılar ülkenin o dönem için acilen gerçek eğitim uzmanlarına ihtiyacının olduğunu göstermektedir (Topçuoğlu, 1969: VIII). Diğer taraftan bizim ülkemizde böyle bir fakülte kurulamaz çünkü bu alanda uzman elemanımız yoktur, ya da biz farklı menşeden gelen elemanları kendi içimize sokmayız, bizim bilgimiz bize yeter gibi fikirler önemli ölçüde engel teşkil eden fikirlerdi (Topçuoğlu, 1969: XVI).

Bunların dışında İstanbul ve Ankara Edebiyat Fakülteleri'nde pedagojipsikoloji derslerinin bulunmasından dolayı bir pedagoji fakültesinin gereksiz bir masraf olacağı sorunu bulunmaktaydı. Ancak Eğitim Fakültesi’nin klasik pedagoji derslerini tekrar etmeyeceği müfredatının amaçlarının ülkenin eğitim meselelerini dünyanın eğitim bilimlerindeki gelişmesine paralel olarak ele almaya ve çözüme kavuşturmaya çalışacağı değerlendirmesi fakültenin kurulmasını kolaylaştırmış oldu (Topçuoğlu, 1969: IX).

Fakültenin kuruluşu esnasında nelerin okutulacağı, hangi modele uygun olacağı önemli bir meseledir o dönemde. Bunu Hamide Topçuoğlu şöyle ifade etmektedir:

Işsi yoluna sokmak için ne yapabiliriz diye düşündüm. Bütün üniversitelere, dünya üniversitelerine mektup yazdım. Sizdeki eğitim fakülteleri nelerdir, hangi dersleri okutursunuz, ne yaparsınız diye? Gayet büyük bir şey geldi, yani yaptığımız işin bir benzeri olduğunu, bir şeye uyduğunu, modele uyduğunu ve diğer üniversitelerden doğan bir şey olduğunu.

Bunu İhsan Doğramacı da şu şekilde belirtmektedir:

Efendim çevre dediğimiz zaman bu çevreyi ille Türkiye çevresine indirgemek doğru olmaz. Biz dünyadaki çeşitli üniversitelerin sistemlerini incelerken buralarda Ë̆itim Fakülteleri'ne ve onun eğitimi koordine eden kuruluşlar, eğitimde pedagojinin yeri nedir, eğitim uzmanlı̆̆ nedir? Bütün bunlar dünya üniversitelerinde nelerdir? Bunu inceledikten sonra bu işe girdik, yoksa Türkiye'den herhangi bir öneri gelmedi. Ingiltere örneği uygun görüldü.

Hamide Topçuoğlu'nun anlatısında da anlaşılabileceği gibi fakültenin kurulması aşamasında yaşanan sorunların yerini fakülte kurulduktan sonra yeni sorunlar almış.

Parasız olduğumuz için çok güçtü. Yönetim ögretim üyesini çă̆ırıyordu ama para vermiyordu. Bütçemiz yoktu. Bazı 
kanunlardan istifade ediyorduk. O bir sene içinde ben bu Fakültenin kuruluş kanunu çıkarttım. Uğraştım ve çıkarttım. Bıraktı̆̆ım zaman kuruluş kanunu olan bir müesseseydi. Başladığım zaman hiçbir şey yoktu ortada. Biz bu bütçeyi çıkartıp, kendi haline getirip kitabına uydurulacak bu bütçe ondan sonra başladık normal safhaya. Babasız çocuk gibi.

Fakültenin kuruluşunun ilk y1llarında özellikle bina sorunu dikkat çekmektedir. Bu eksikliğin giderilmesi için Hukuk Fakültesi ve İlahiyat Fakültesi'nin önemli desteği olmuştur. Eğitim Fakültesi başlangıçta dekanlık ve sekreterlik işlerini tek oda içinde yürütmek zorunda kalmıştır. Fakültenin ilk y1lında öğrenciler Hukuk Fakültesi'nin vermiş olduğu bir derslikte öğretimini sürdürmüştür. Gerek duyulduğunda öğleden sonraki dersler için de Hukuk Fakültesi'nin dersliklerinden faydalanılmıştır. Büro işlemleri için de İlahiyat Fakültesi'nden, personel ihtiyacı durumunda da Hacettepe Tip ve Sağlık Bilimleri Fakültesi'nin asistan ve okutmanlarından yararlanılmıştır (Topçuoğlu, 1969).

İhsan Doğramac1 Hamide Topçuoğlu'nun aksine uzman edinme konusunda pek fazla sorun yaşanmadığını belirtmektedir:

Hayır değil. Genelde siz istedikten sonra bu alanda uzmanlaşmış ve yahut ta ilgi duymuş kişileri bulabilirsiniz. Hatta ille bu işin en mükemmelini aramaktansa, siz daha çok gençlerden yararlanabilirsiniz. Onlar kendilerini yetiştirirler. Bugün bir üniversiteyi bitiren hatta doktorasını tamamlayan hatta profesör olan kişiler her gün kendini yenilemek gerek zorunluluğunda. Her gün bilim değişiyor. Bundan on sene önceki eğitim ve yahut ta bilimlerin bugün bir kısmı geçersiz sayllyyor. Onun için ille bunu, her şeyi bilen değil, her şeyi ögrenmek isteyen gençler bulunca başarl sizindir.

"Fakültenin üniversite tarafindan önemsenme durumunu İhsan Doğramacı şöyle anılaştırmaktadır:

Artık bu önemsememe diye bir şey yok. Yeni bir fakülte kurulmuştur ona olanaklar sağlamak gerekiyor. Ve ben 63 yllında rektörlüğe başladı̆̆ım zaman Ankara Üniversitesi'nde bina sorunlarl vardı. Ve şunu da söyleyeyim, ben rektörlüğe başladı̆̆ım gün biz Devlet Planlama Teşkilatı'yla sıkı işbirliği yaparak, her fakülteye bir ve ya iki yeni bina ekledik. Ve iki sene içinde bütün bunlar tamamlandl. Tip Fakültesi'nin morfoloji binası karkas haldeydi yıllardır. İki sene sonra onun da anahtarını bitmiş olarak fakülte dekanlı̆̆ına teslim ettik. Ve böylece bu iki senede yapı, araç, gereç bakımından sıkıntımız 
olmadı, Bu da Devlet Planlama Teşkilatı'yla sıkı işbirliği sayesinde oldu.

\section{c) Eğitim Fakültesi’nin Kuruluştan Sonraki Kısa Seyri}

Fakültenin ilk yılında birinci sınıfta altı Türk profesörü ve bir yabancı profesörü, bir Türk danışmanı, üç yabancı dil uzmanı vardı. Elli öğrenci sayısı kısa bir süre sonra doksana, daha sonra 1966-7 döneminde de bu sayı iki yüze çıkmış oldu (Topçuoğlu, 1969: XXI-XXV). Fakültenin ilk iki yılık öğretim devresinden sonra, üçüncü yıldan itibaren öğrencilerin, ileride çalışacakları alanlara göre lisans-içi ihtisas bölümlerine ayırmaya karar verildi. Yönetmeliğe göre fakültenin üçüncü ve dördüncü sınıflarında, öğrenciler üç uzmanlık alanından birine yazılacaklardı, istisnai olarak ikinci bir uzmanlık alanını da birlikte almak ve bunu mezuniyetten en geç bir yıl içinde tamamlamak olanağına sahip olacaklardı. Lisans-içi ihtisas bölümleri şunlardı: a) Okul Psikologluğu ve Rehberlik Bölümü, b) Eğitim İdareciliği ve Planlama Bölümü, c) Özel Eğitim Bölümü (Topçuoğlu, 1969: XXVIXXVII).

Daha önce sözünü ettiğimiz kadro kanununa kavuşmak fakülte için önemli bir teselli kaynağı olmuştu. Çünkü o güne kadar fakülte üniversitenin sınırlı olanaklarıyla ayakta durmaya çalışmaktaydı. Bu kanunun çıkmasından sonra bir sonraki ders yılında yeni öğretim üyeleri alabilmek için dört aylık bir ek bütçe kanun teklifinde bulunulmuştu. Ancak, usulen geçmesi gereken kademlerden işler geciktiği için 1966 yılının son mali ayı içinde kullanılabilinecek şekilde kanunlaşabildi. Bu zamanlama sorunu öğretim elemanlarının atamalarında sikıntılara neden olmaktaydı. $\mathrm{Bu}$ yüzden üniversitelerin mali statülerinin o dönem için sorunları çözemediğini ileri sürmek mümkündür (Topçuoğlu, 1969: XXIV).

Fakülte bu sıkıntıya rağmen çalışmalarını devam ettirmeye çalışmakta ve 1965-1969 tarihleri arasında aşağıda adı geçen bölümlerin kurulmasını başarabilmişti. Bu bölümler şunlardı: a) Eğitim Yönetimi ve Teftişi Bölümü, b) Eğitim Ekonomisi ve Planlanması Bölümü, c) Eğitimin Sosyal ve Tarihi Temelleri Bölümü, d) Eğitim Programları ve Öğretim Bölümü, e) Halk Eğitimi Bölümü, f) Özel Eğitim Bölümü, g) Teknik Eğitim Bölümü, ğ) Güzel Sanatlar Eğitimi Kürsüsü, h) İstatistik ve Araştırma Eğitimi Bölümü, 1) Eğitim Araştırmaları Merkezi (Mıhçıŏlu, 1989: 360).

1981 yılında çıkan 2547 sayılı Yükseköğretim Kanunu'nun getirmiş olduğu yeni düzenlemeyle fakültenin durumunda önemli değişiklikler oldu. (Mıhçıŏlu, 1989:362-363). 1982 yılında tüm öğretmen yetiştiren kurumların "Eğitim Fakültesi" adını almaları üzerine başlangıçta Eğitim Fakültesi adıyla kurulan bu Fakülte adı diğer fakültelerden farklılı̆̆ını 
koruması için 1983 yılında 2809 sayılı yasayla Eğitim Bilimleri Fakültesi olarak değiştirildi. (Koç, 2008). 1980'den sonra fakültedeki bölüm sayısı üçe indirilmiş oldu. Bunlar: Eğitim Yönetimi ve Planlanması Bölümü, Eğitimde Psikolojik Hizmetler Bölümü, Eğitim Programları ve Öğretim Bölümü. Aynı zamanda bu dönemde fakültenin öğretim kadrosunda da önemli bir azalma oldu. 1980 öncesinde doksanın üstünde olan öğretim elemanı sayısı kırklara inmiş oldu fakülte taşra üniversitelerinden öğretim elemanı temin eder duruma geldi ( Mihçıŏlu, 1989: 362-363).

Eğitim Bilimleri Fakültesi ilk mezunlarını verdiği 1969 tarihinden 1998 tarihine kadar lisans düzeyinde 4731 mezun vermiştir. Mezunların bölümlere dağılımı şu şekildedir:

$\begin{array}{lllll}\text { Bölümler } & & \text { kiz } & \text { erkek } & \text { toplam } \\ \text { Eğitimde Psikolojik Hizmetler } & & & & \\ \text { Eğitim Programları ve Öğretim } & : & 885 & 684 & 1569 \\ \text { Eğitim Yönetimi ve Planlanması } & : & 485 & 753 & 1285 \\ \text { Halk Eğitimi } & : & 70 & 93 & 1633 \\ \text { Özel Eğitim } & : & 27 & 54 & 81 \\ \text { Toplam } & : & \mathbf{1 9 9 9} & \mathbf{2 7 3 2} & \mathbf{4 7 3 1}\end{array}$

Daha önce de belirtildiği gibi fakültenin temel amaçlarından biri, eğitim bilimleri alanında uzman yetiștirmektir. Mezunların büyük bir oranı 1985 yılına kadar Milli Eğitim Bakanlığı'nda ve diğer kuruluşların eğitim birimlerinde uzman yardımcısı ya da uzman olarak istihdam edilmişlerdir (Koç, 1999: 25).

Eğitim Bilimleri Fakültesi'nin 1969 tarihinden bu yana yürütmüş olduğu önemli programlardan birisi de Lisansüstü Eğitim Programları'dır. Fakültenin değişik bölüm ve anabilim dallarından eğitimin çeşitli uzmanlık alanlarında 1974-1998 seneleri arasında 750 yüksek lisans ve 192 doktora olmak üzere toplam 942 kişi lisansüstü programlarından mezun olmuştur. 1967-1968 öğretim y1lından itibaren öğretmenlik sertifikası programları düzenleyen fakülte bu programlarından 1997-1998 öğretim yılı sonu itibariyle 5167 mezun vermiştir. Bunun dışında ayrıca Eğitim Fakülteleri'nde görev yapan eğitim bilimlerinin değişik ihtisas alanlarındaki akademisyenlerin büyük bir kısmının da Eğitim Bilimleri Fakültesi mezunu olduğu görülmektedir (Koç, 1999: 27-28). 


\section{SONUC}

Daha sonra adı Eğitim Bilimleri Fakültesi olarak değiştirilen Ankara Üniversitesi Eğitim Fakültesi'nin kuruluşu ve kuruluş sürecinde yaşananlar, Eğitim Fakültesinin önemi ve gerekliliği konusunda devletin ve akademik çevrenin bakış açısını ortaya koymaktadır. Öncelikle Cumhuriyet'in kuruluşundan kırk üç yıl sonra bir Eğitim Fakültesinin kurulmuş olması hakikaten üzerinde durulması gereken önemli bir meseledir. Daha önce sözünü ettiğimiz önyargı ve yaklaşımların bu kuruluş sürecinin uzamasında önemli bir rol üstlendiği kesindir. Fakültenin kuruluş süreci pek çok güçlükleri de beraberinde getirmiştir. $\mathrm{Bu}$ güçlüklerin üstesinden gelmek üniversite bünyesindeki bir grup akademisyenin önemli çabalarıyla mümkün olmuştur. $\mathrm{Bu}$ gayretleri görüşme yaptığımız üç hocanın da anlatılarında bulabilmekteyiz. Özellikle Prof. Dr. Hamide Topçuoğlu ve Prof. Dr. Yaşar Karayalçın'nın anlatıları bu durumu tüm berraklığıyla ortaya koymaktadır. $\mathrm{Bu}$ anlatılarda Fakültenin kuruluş ve eğitim öğretiminin ilk yıllarında yaşanmış olan güçlükler ve bunlara çözüm olabilecek çabaları bulabilmekteyiz. Yazılı belgelerde ise daha çok Fakültenin kuruluşuna yönelik girişim ve yasal düzenlemelere rastlamaktayız.

Ayrıca eğitim kurumlarının siyasiler tarafından gerektiği düzeyde önem görmemesi böyle bir Fakülte'nin kurulma ihtiyacını hem geciktirmiş hem de kuruluş sürecindeki engelleri de beraberinde getirmiştir. Hükümetlerin 1965 tarihine kadar eğitim fakültesi/leri kurma girişiminde bulunmayışları hatta bu tarihte tüm zorluklara rağmen kurulmuş olan Ankara Üniversitesi Eğitim Fakültesi'nin işleyişini kolaylaştıracak yasal düzenlemeleri geciktirmiş olmaları üzerinde dikkatlice düşünülmesi gereken bir konudur. Dönemin Milli Eğitim Bakanlığı Müsteşarı Nuri Kodamanoğlu'nun eğitime yönelik çabaları ve Fakülte'nin kuruluşuna özgü raporu böyle bir fakültenin ihtiyaç olduğunu dile getirmektedir. $\mathrm{Bu}$ raporun yanı sıra Eğitim Fakültesinin kurulması için önemli girişimler olmuştur, ayrıca bu çabaların bazı izlerini de VII. Milli Eğitim Şurası ve MEHTAP Raporu'nda da görebilmekteyiz.

Fakülte'nin kuruluş süreciyle ilgili anlatılarda bu işin çok programlı işlemediği ve sürecin pek çok güçlüğü beraberinde getirdiği görülmektedir. $\mathrm{Bu}$ anlatılarda, fakültenin kuruluşuna yönelik ciddi bir talebin akademik çevre ve toplumdan gelmediği anlaşılmaktadır. Fakültenin kurulmasına ilişkin talep daha çok eğitim bilimi ile doğrudan bağlantısı olmayan akademisyen ve bürokratlardan geldiği görülmektedir. $\mathrm{Bu}$ kişilerin, fakültenin işlevini yerine getirebilmesi için önemli ölçüde çaba sarf ettikleri anlaşılmaktadır.

Önemli gayretlerden sonra salt Fakülte'nin kurulmas1 sorunu çözmemiştir. Anlatılarda da görülebileceği gibi Fakültenin altyapısının yetersiz olduğu, gerek derslik gerekse öğretim elemanı temininde önemli 
sıkıntıların yaşandığı anlaşılmaktadır. Büyük çabalar verilerek kurulan Fakülte kuruluşundan bu yana önemli ölçüde eğitim uzmanı, öğretmen adayı mezun etmiş ve eğitim içerikli bilimsel çalışmalarla da eğitime büyük katkı sağlamıştır. 1965'ten önceki 43 yılda Eğitim Fakültesi olmayan bir Türkiye'nin eğitim-öğretim kurumlarında çalışan eğitimcilerin yetersizliği ya da yeterli sayıda eğitimciye sahip olmayışı bize bu sürede büyük bir kayıbım olduğunu göstermektedir.

\section{KAYNAKLAR}

Ataman, A., Dirik, Z., Koç, N. (1976). Ankara Üniversitesi Eğitim Fakültesi, Mezunlar 'Lisans Düzeyinde' 1965-1975. Ankara Üniversitesi Eğitim Fakültesi 10. Yıl Yayınları, no: 4.

Aydın, İ., Kepenekçi, Y. K. (2008) Ankara Üniversitesi Eğitim (Bilimleri) Fakültesi'nin Kurucularından Prof. Dr. Yaşar Karayalçın: Yaşam ve Eğitim (Bilimleri) Fakültesi Öyküsü. Ankara Üniversitesi Eğitim Bilimleri Fakültesi Dergisi, cilt 41, sayı, özel say1, 93-112.

Caunce, S. (1994). Oral History and the Local Historian. London: Longman.

Çavdar, C. (1976). Ankara Üniversitesi Eğitim Fakültesi 1975-1976. Ankara Üniversitesi Eğitim Fakültesi 10. Yı1 Yayınları no: 1.

Koç, N. (2008). Eğitim Bilimleri Fakültesi (1964-2008): Eğitim Bilimlerinin Kurumsallaşmasına ve Öğretmen Yetiştirmeye Katkıları Açısından Bir Değerlendirme. Ankara Üniversitesi Ĕ̆itim Bilimleri Fakültesi Dergisi , cilt 41, say1, özel say1, 23-47.

Koç, N. (3-4 Mart 1999). Ülkemizde Eüitim Bilimlerinin Gelişmesine Ankara Üniversitesi Eğitim Bilimleri Fakültesinin Katkıları. Öğretim Birliğinin 75. Yılı Eğitim Bilimlerinin Dünü, Bugünü ve Yarını adlı sempozyumda sunuldu. Ankara.

Kodamanoğlu, N. (1964). Üniversitelerimize Bağlı Eğitim Fakülteleri Kurulması Hakkında Rapor. Milli Eğitim Bakanlığı.

Mihçıŏlu, C. (1989). Eğitim (Bilimleri) Fakültesinin Kuruluşu Üzerine. Eğitim Bilimleri Fakültesi Dergisi, (22) sayı: 1, 347-360.

Milli Eğitim Bakanlığı. (1962). VII. Milli Eğitim Şurası. Ankara: Milli Eğitim Bakanlığı Basımevi.

Öztürkmen, A. (2001). Celebrating National Holidays in Turkey: History and Memory. New Perspectives on Turkey, 25, 47-75.

Sağlam, M. (2010). “1970-1975 Dönemi İlkokul Öğrencilerinin Eğitim Deneyimler: Sözlü Tarih Yöntemiyle bir Çalışma.” Yayımlanmamış Doktora tezi, Ankara Üniversitesi Eğitim Bilimleri Enstitüsü, Ankara.

Starr, L. (1984). Oral History. In David K. Dunaway and Willa K. Baum (Eds.), Oral History an Interdisciplinary Anthology (39-61). London: Altamira.

Tan, M. (2000). An Oral History Project with the 'Children of the Republic' IOHA Conference Istanbul, I'de sunuldu. İstanbul, 346-355. 
Tan, M. (1996). Çocukluğun Tarihi Araştırmalarında Sözlü Tarih Yaklaşımı ve Sözlü Tarihte Bir Çocuk. Çocuk Kültürü, I. Ulusal Çocuk Kültürü Kongresi'nde sunuldu. Ankara, 31-56.

Topçuoğlu, H. (1969). Ankara Üniversitesinin Bir 'Eğitim Fakültesi' Vardır!. Eğitim Fakültesi Dergisi, (2). VI-L.

Tuncay, N. E. (1993). Sözlü Tarih Atölyesi. İstanbul: Tarih Vakfı Yayınları.

Türkiye ve Orta Doğu Amme İdaresi Enstitüsü. (1966). Merkezi Hükümet Teşkilatı Araştırma Projesi. Ankara: Türkiye ve Orta Doğu Amme İdaresi Enstitüsü Yayınları. 